\title{
Comparative analysis of heat pump and biomass boiler for small detached house heating
}

\author{
Tomasz Olkowski ${ }^{1, *}$, Seweryn Lipiński ${ }^{1}$, and Aneta Olędzka ${ }^{1}$ \\ ${ }^{1}$ Department of Electric and Power Engineering, Electronics and Automation, Faculty of Technical Sciences, \\ University of Warmia and Mazury in Olsztyn, 11 Oczapowskiego St., 10-736 Olsztyn, Poland
}

\begin{abstract}
The purpose of the work is to answer the question - which of the two selected heat sources is more economically beneficial for small detached house: heat pump or biomass boiler fuelled with woodpellets? The comparative analysis of these sources was carried out to discuss the issue. First, cost of both, equipment and operation of selected heat systems were analysed. Additionally, $\mathrm{CO}_{2}$ emission levels associated with these heat systems were determined. The comparative analysis of the costs of both considered heat systems showed that equipment cost of heat pump system is considerably bigger than the cost of biomass boiler system. The comparison of annual operation costs showed that heat pump operation cost is slightly lower than operation cost of biomass boiler. The analysis of above results shows that lower operation cost of heat pump in comparison with biomass boiler cost lets qualify heat pump as more economically justified only after 38 years of work. For both analysed devices, $\mathrm{CO}_{2}$ emission levels were determined. The considerations take into account the fact that heat pump consumes electricity. It is mostly generated through combustion of coal in Poland. The results show that in Poland biomass boiler can be described as not only more economically justified system but also as considerably more ecological.
\end{abstract}

\section{Introduction}

The analysis of the Central Statistical Office (CSO) data [1] with regard to the number of residences delivered for use over the period from 1991 to 2016 shows the growing trend of private construction, i.e. detached houses (including single-family houses) in relation to the total construction. An average from the analysed 26 years is approx. 58 thousand detached houses of private construction per year, i.e. $49 \%$ of total construction.

These buildings need individual heat sources to in order to heat space, as well as domestic hot water (d.h.w.). In currently built Polish detached houses electricity and heat consumption is significantly lower than in the older ones [2], but still households' energy consumption represents a significant part $(33 \%)$ of energy balance in Poland $[3,4]$. Space heating has the largest share in the structure of energy consumption by Polish households (approx. 69\%) [2]. It suggests that space heating represents a heavy financial burden for households' owners. That is why it is important to use the least costly heat sources, but of course considering energy efficiency and environmental requirements.

It is difficult to select heating devices from those being used in detached houses, which meet all the abovementioned conditions. However, it can be assumed that heating devices are more ecological when they use renewable energy sources (RES) [5], and when they are energy-efficient $[6,7]$.
High efficiency of a heating equipment results in lower operational costs, but advanced technical solutions are usually needed to produce such devices. For that reason, the energy-efficient equipment has often a higher price [8] and that is why the selection of a heating system should always be preceded by a thorough economic analysis.

In this paper, two kinds of heating systems were considered. These are system with a heat pump (HP), as well as system with a wood pellet firing boiler (biomass boiler). Both are RES-based and seem the most ecological and energy-efficient $[9,10]$. The main purpose of the work is to answer the following question: which of the two selected heat sources is more economically beneficial for small detached house? The comparative analysis of these sources was carried out to discuss the issue. First, cost of both, equipment and operation of selected heat systems were analysed. Additionally, $\mathrm{CO}_{2}$ emission levels associated with these heat systems were determined. It should be underlined that this analysis concerns only Polish conditions, what can have a significant impact on the obtained results.

Similar analyses for other countries can be found e.g. in following papers: [8,11-13].

\section{Material and methods}

The analysis was carried out for a non-existing detached house. It was designed for the sole purpose of this study.

* Corresponding author: tomasz.olkowski@uwm.edu.pl 
The „Audytor OZC 6.6 Pro Edu” and „Audytor C.O. 4.0 Edu" software were used during design.

The house is supposed to be located in north-eastern part of Poland in the town of Kętrzyn, i.e. in the fourth climatic zone with reference external design temperature equal to $-22^{\circ} \mathrm{C}$ [14]. The house has one habitation floor over the ground level and non-habitable (unheated) attic space. The house is to be built from cellular concrete blocks. External and internal wall thickness amount to 24 and $12 \mathrm{~cm}$, respectively. The ceiling is to be made out of oak wood, which is a very good insulator. The whole building is to be placed on the foundation footings and benches directly on the ground. The total habitation area of the house amounts to $141.45 \mathrm{~m}^{2}$ (Table 1); the number of home residents is five persons. It was assumed that the presented house does not have access to the natural gas network but it is connected to the electricity grid, water supply and sewage system.

Table 1. The area and the heating demand of rooms in the analysed detached house.

\begin{tabular}{|c|c|c|}
\hline & Area $\left[\mathbf{m}^{2}\right]$ & Heating demand [W] \\
\hline Hall & 9.9 & 540 \\
\hline Boiler-room & 6.66 & 0 \\
\hline Kitchen & 16.92 & 989 \\
\hline Bathroom & 11.7 & 701 \\
\hline Room I & 18.68 & 898 \\
\hline Room II & 15.75 & 772 \\
\hline Living room & 61.85 & 2431 \\
\hline TOTAL & 141.45 & 6331 \\
\hline
\end{tabular}

Table 1 shows the design heat load for each room in the house. The design heat load of boiler-room is equal to zero, because boiler-rooms are designed as unheated areas and so the total heated area equals $134.8 \mathrm{~m}^{2}$.

The analysis of the data from Table 1 shows that rooms heating energy demand $\left(\Phi_{c o}\right)$ amounts to $6.3 \mathrm{~kW}$. Domestic hot water heating energy demand is also needed to be known $\left(\Phi_{c w u}\right)$ in order to calculate the total energy demand of the house. The daily domestic hot water energy demand can be calculated using formula (1), taking into account $20 \%$ heat loss caused by water flow in the pipelines:

$$
\Phi_{c w u}=Q_{c w u} / 24 \mathrm{~h}+20 \%,
$$

where $Q_{c w u}$ is daily d.h.w. heat demand.

Daily domestic hot water heat demand can be calculated using following formula:

$$
Q_{c w u}=c \rho V\left(t_{c w}-t_{z w}\right),
$$

where $c$ is specific heat of water $(4,19 \mathrm{~kJ} /(\mathrm{kg} \mathrm{K})), \rho$ is water density $\left(1000 \mathrm{~kg} / \mathrm{m}^{3}\right), V$ is daily water demand of water to be heated $\left(0,5 \mathrm{~m}^{3}\right), t_{c w}$ is hot water temperature $\left(55^{\circ} \mathrm{C}\right)$ and $t_{z w}$ is cold water temperature $\left(10^{\circ} \mathrm{C}\right)$.

A daily demand of water to be heated $(V)$ was assumed based on [15]. According to it, daily use of a water in a dwelling house connected to sewage system equals $100 \mathrm{dm}^{3}$ per one home resident. Using above data, $\Phi_{c w u}=1.32 \mathrm{~kW}$ was calculated and so the total design heat load of the house $\left(\Phi_{C}\right)$ is possible to be obtained using the formula:

$$
\Phi_{C}=\Phi_{c o}+\Phi_{c w u}
$$

Based on the above data, the total design heat load of the house equals $7.6 \mathrm{~kW}$. It was assumed that one of the two selected heat sources, i.e. heat pump or biomass boiler fuelled with wood-pellets can be exploited in the considered house.

Energy balance of the house is shown in Fig. 1. It includes heat losses and gains. The results shown in Fig. 1 show that supposed solar heat gains and heat gains from household devices represent an important share of the house energy balance. It will allow to reduce the planned heating system cost.

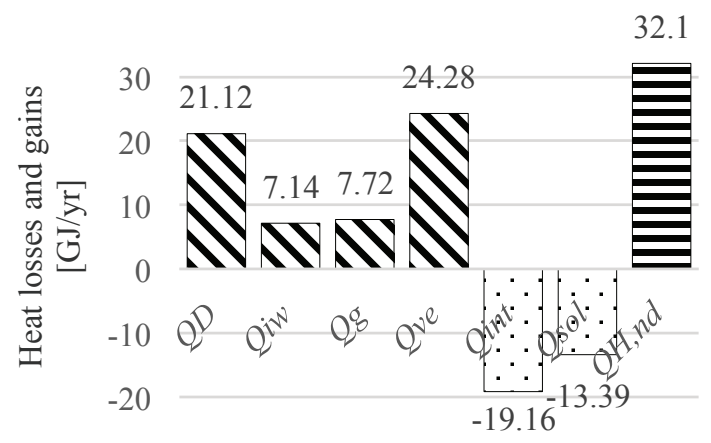

Fig. 1. Energy balance of the house $[\mathrm{GJ} / \mathrm{yr}]: Q_{D}-$ heat losses through external walls, $Q_{i w}$ - heat losses through internal walls, $Q_{g}$ - heat losses to the ground, $Q_{v e}$ - natural ventilation heat losses, $Q_{\text {int }}$ - heat gains from household devices, $Q_{\text {sol }}$ - gains from solar heat, $Q_{H, n d}$ - annual heat needs of the house with the use of heat gains factor $\eta_{H, g n}=0.87$.

For each of the considered heat sources an economic analysis was made. The purpose of this analysis is identification and comparison of cost of equipment and operation of heating devices and systems that make up a given heat source. In this case, the investment costs include the purchase costs of equipment, but do not include manual labour costs. Operating costs include the purchase of fuel and electricity and the cost of equipment service. Based on the economic analysis, a simple payback period of investment in the considered heat sources was calculated.

In addition, the ecological analysis of the heat sources was carried out. The $\mathrm{CO}_{2}$ emissions from fuels combustion and electricity consumption were analysed. Under Polish conditions, electricity is mainly produced by hard coal combustion, which results in significant $\mathrm{CO}_{2}$ emissions.

\section{Identification of heat sources for comparative analysis}

\subsection{Heat pump}

First of the selected systems is heat pump with a $9 \mathrm{~kW}$ maximum heating power output. 
Table 2 shows other parameters of the chosen heat pump.

Table 2. Parameters of the selected heat pump.

\begin{tabular}{|l|c|}
\hline \multicolumn{1}{|c|}{ Parameter } & Value \\
\hline Heating power & $9 \mathrm{~kW}$ \\
\hline Power consumption & $1.7 \mathrm{~kW}$ \\
\hline Cooling power & $7.3 \mathrm{~kW}$ \\
\hline COP & 5.2 \\
\hline $\begin{array}{l}\text { Supply temperature of heating installation } \\
\text { (at heat pump outlet) }\end{array}$ & $35^{\circ} \mathrm{C}$ \\
\hline Brine temperature (at heat pump inlet) & $5^{\circ} \mathrm{C}$ \\
\hline
\end{tabular}

Such power of heat pump results from the possible interruptions in the electricity supply during periods of peak load in the electrical grid [16]; in order to ensure proper work, an oversize device is required. A time of interruption in the electricity supply was assumed as equal to $2 \mathrm{~h}$, with the oversizing factor equal to 1.1 and so the heat pump with $8.4 \mathrm{~kW}$ minimum heating power output is required.

As a lower heat source, a flat ground heat exchanger was selected. It is immersed in the ground of aquifers gravel and sand, with a unit heating power output of 32 $\mathrm{W} / \mathrm{m}^{2}$. This is one of the best types of soil for flat heat exchangers, because the more wet the soil, the higher the heat transfer coefficient, and so the more favourable heat transfer conditions [17].

The view of the habitation floor with layout of heating surfaces and shore zones is shown in Fig. 2.

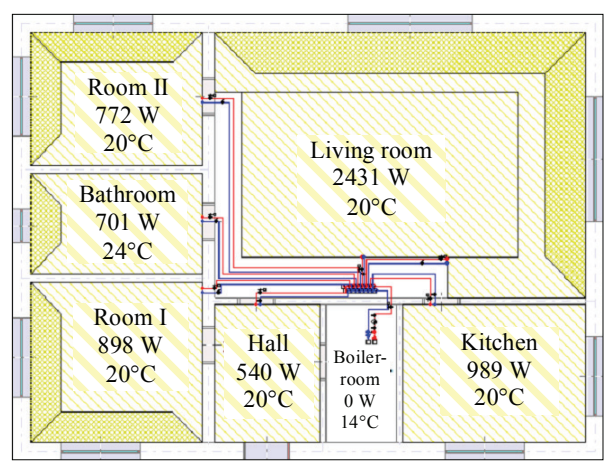

Fig. 2. The view of the habitation floor with layout of heating surfaces and shore zones.

An underfloor heating works as a higher heat source for the heat pump. Such configuration will ensure proper system operation, i.e. protection of the floor from overheating as well as work of the heating device with the highest possible efficiency. An installation of underfloor heating with a $5433 \mathrm{~W}$ heating power was designed.

The reason for the lack of shore zone in the kitchen (Fig. 2) is the relatively high heat gain from household goods - identified in the energy balance of the house (Fig. 1). In the hall, no shore zone was designed as its heat demand would be covered by heat gains from neighbouring rooms. The living room was divided into two heating surfaces with heating loops of 87 and $119 \mathrm{~m}$, to avoid exceeding the allowable heating loop length equal to $120 \mathrm{~m}$.

The equipment and operation costs have been identified for such heating system. The individual components of the equipment cost are given in Table 3 .

Table 3. The equipment cost of heat pump including installations of lower and higher heat sources.

\begin{tabular}{|l|c|}
\hline \multicolumn{1}{|c|}{ Specification } & Cost [USD] \\
\hline $\begin{array}{l}\text { Heat pump with built-in domestic hot } \\
\text { water tank }\end{array}$ & 6255.33 \\
\hline Lower heat source - ground heat exchanger installation \\
\hline $\begin{array}{l}\text { Lower heat source equipment } \\
\text { (collector pipes - 285 m, manifold - } \\
3 \text { circuits) }\end{array}$ & 439.39 \\
\hline $\begin{array}{l}\text { Glandless circulation pump, safety } \\
\text { group, diaphragm expansion vessel }\end{array}$ & 368.00 \\
\hline Glycol - approx. 300 dm ${ }^{3}$ & 1030.40 \\
\hline Total (lower heat source) & 1837.79 \\
\hline \multicolumn{1}{|c|}{ Higher heat source - heating flat installation } \\
\hline Pipes of heating loops - 563 m & 580.21 \\
\hline Insulation & 414.61 \\
\hline $\begin{array}{l}\text { Clips, edge band, manifold - } \\
\text { circuits, circulation pump, ball valve } \\
\text { (9 pcs) }\end{array}$ & 538.01 \\
\hline Automatic balancing valve (8 pcs) & 785.06 \\
\hline $\begin{array}{l}\text { Plasticizer, adhesive tape, couplings, } \\
\text { expansion joint, expansion tape, } \\
\text { peschel }\end{array}$ & 123.16 \\
\hline Flush-mounted cabinet & 62.31 \\
\hline $\begin{array}{l}\text { Expansion tank closed for rooms } \\
\text { heating - 8 dm }\end{array}$ & 17.66 \\
\hline Total (higher heat source) & 2521.02 \\
\hline Total equipment cost & $\mathbf{1 0 6 1 4 . 1 6}$ \\
\hline
\end{tabular}

Equipment cost may be reduced by subsidies. The subvention can be obtained from the National Fund for Environmental Protection and Water Management under the „Prosument” program [18]. The amount of subsidy is up to $15 \%$ of eligible costs, which is approx. $1,821.60$ USD in this case. Thus, if the subsidy is taken into account, the equipment cost for the heat pump installation is equal to 8,792.54 USD. This amount will be taken into account during calculation of the payback period of investment in heat pump installation.

During calculation of the operation cost, it was assumed (based on [19]), that the working time of the heat pump for Kętrzyn is 2,426 h/yr. It allows calculating the annual electricity consumption by the heat pump as $4,124.2 \mathrm{kWh} / \mathrm{yr}$. Results of the operation cost calculation are given in Table 4.

Table 4. The operation cost for heat pump heating system.

\begin{tabular}{|l|c|}
\hline \multicolumn{1}{|c|}{ Specification } & Cost [USD/yr] \\
\hline $\begin{array}{l}\text { Annual cost of electricity } \\
\text { consumption by heat pump }\end{array}$ & 618.63 \\
\hline $\begin{array}{l}\text { Annual cost of electricity } \\
\text { consumption by circulation pumps } \\
\text { of the lower and higher heat sources }\end{array}$ & 15.00 \\
\hline Service of the heat pump equipment & 122.67 \\
\hline Total operation cost & $\mathbf{7 5 6 . 3 0}$ \\
\hline
\end{tabular}


The electricity price of $0.15 \mathrm{USD} / \mathrm{kWh}$ was assumed for a single-zone tariff for households (G11). The electricity consumption of each of the used circulation pumps (one in the lower and one in the higher installation) is approx. $50 \mathrm{kWh} / \mathrm{yr}$. Service (including the heat exchanger cleaning) is approx. 122.67 USD/yr. Although equipment cost can be a serious financial burden for an investor, total operation cost (Table 4) of $756.30 \mathrm{USD} / \mathrm{yr}$ is not too high in Polish conditions.

\subsection{Biomass boiler}

A biomass boiler is an alternative for the heat pump. The correct choice of the boiler depends mainly on the design heat load of the building. Other and equally important reasons for choosing a particular boiler are availability and price of the proper fuel, the cost of purchasing and installing the boiler, as well as the cost and comfort of using the boiler.

Taking the design heat load of the house into consideration, the smallest biomass boiler with retort furnace fuelled with wood-pellets (which is available on the domestic market) was chosen. The nominal heating power of the boiler amounts to $9 \mathrm{~kW}$, but it can work in the range of $3 \div 10 \mathrm{~kW}$. When working with a nominal heating power, this boiler can achieve up to $86 \%$ efficiency. The technical specifications of the selected boiler are shown in Table 5.

Table 5. Technical parameters of the selected boiler.

\begin{tabular}{|l|c|}
\hline \multicolumn{1}{|c|}{ Parameter } & Value \\
\hline Nominal heating power & $9 \mathrm{~kW}$ \\
\hline Range of work & $3 \div 10 \mathrm{~kW}$ \\
\hline $\begin{array}{l}\text { Boiler working time without filling fuel } \\
\text { (nom. heating power } \div \text { min. heating power) }\end{array}$ & $50 \div 130 \mathrm{~h}$ \\
\hline Water capacity of the boiler & $45 \mathrm{dm}^{3}$ \\
\hline Min. chimney draft required & $24 \div 34 \mathrm{~Pa}$ \\
\hline Maximum operating pressure & $1.5 \mathrm{bar}$ \\
\hline Diameter of the flue & $159 \mathrm{~mm}$ \\
\hline
\end{tabular}

For the boiler, a central heating system consisting of plate heaters with a total heat output of 4709 W was designed. A double-walled heat exchanger with a capacity of $120 \mathrm{dm}^{3}$ for domestic hot water heating was also selected. The heating installation diagram is shown in Fig. 3.

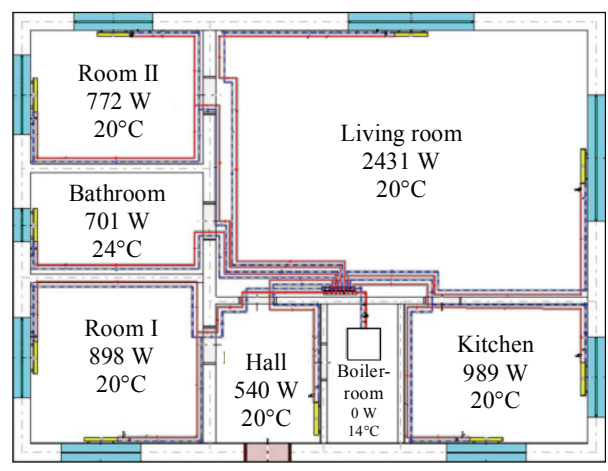

Fig. 3. The heating installation diagram.
For the heating system with biomass boiler, the equipment and operation costs have been also identified, as for the system with heat pump. The individual components of the equipment cost are given in Table 6 .

Table 6. The equipment cost of the heating system with biomass boiler.

\begin{tabular}{|l|c|}
\hline \multicolumn{1}{|c|}{ Specification } & Cost [USD] \\
\hline \multicolumn{2}{|c|}{ Heat source } \\
\hline Biomass boiler & 1616.99 \\
\hline $\begin{array}{l}\text { Double-walled heat exchanger 120 } \\
\mathrm{dm}^{3}\end{array}$ & 176.64 \\
\hline Total (heat source) & 1793.63 \\
\hline \multicolumn{2}{|c|}{ An installation for heat collection } \\
\hline Plate heater C11-60 (3 pcs) & 220.80 \\
\hline Plate heater C11-30 (5 pcs) & 288.27 \\
\hline Plate heater C21S (2 pcs) & 180.56 \\
\hline $\begin{array}{l}\text { Open expansion vessel reflex 25 dm } \\
\text { ball valve (2 pcs), manifold - 7 } \\
\text { circuits, angle radial return valve (10 } \\
\text { pcs), glandless circulation pump }\end{array}$ & 545.62 \\
\hline $\begin{array}{l}\text { Automatic balancing valve ASV-P } \\
\text { (10 pcs) }\end{array}$ & 1077.01 \\
\hline $\begin{array}{l}\text { Pipe guide at the manifold (38 pcs), } \\
\text { pipes PEAL-S10 - 191,82 m, } \\
\text { thermostatic heads (7 pcs), flush- } \\
\text { mounted cabinet, peschel }\end{array}$ & 350.51 \\
\hline $\begin{array}{l}\text { Total (an installation for heat } \\
\text { collection) }\end{array}$ & 2662.77 \\
\hline Total equipment cost & $\mathbf{4 4 5 6 . 4 0}$ \\
\hline
\end{tabular}

In the case of a biomass boiler, it is also possible to apply for a subvention in order to cover a part of equipment cost from the same program as for a heat pump. The amount of this subsidy is also up to $15 \%$ of eligible costs, which is approx. 596.16 USD. Thus, after this subsidy is taken into account, the equipment cost for a biomass boiler system is equal to 3860.24 USD. As with heat pumps, this cost will be taken into account during calculating the payback period of investment in the biomass boiler installation.

Table 7 shows the operation cost of a pellet boiler heating system. Based on [20], the price of pellets of 208.53 USD/t and annual use of pellets (3.8 t) was assumed. The electrical power consumption of the pellets feeder, blast furnace and circulation pump is approx. $1.7 \mathrm{kWh} /$ day. Operation of the biomass boiler does not require regular service, like in the case of heat pump. The annual operating time of the pellet boiler is similar to a time of the heat pump work, so the value is the same, i.e. $2426 \mathrm{~h} / \mathrm{yr}$ [19]. In addition, the price of electricity is the same, i.e. $0.15 \mathrm{USD} / \mathrm{kWh}$.

Table 7. The operation cost for pellets boiler heating system.

\begin{tabular}{|l|c|}
\hline \multicolumn{1}{|c|}{ Specification } & $\begin{array}{c}\text { Cost } \\
\text { [USD/yr] }\end{array}$ \\
\hline Cost of pellet using & 792.41 \\
\hline Annual electricity cost & 93.03 \\
\hline Total operation cost & $\mathbf{8 8 5 . 4 4}$ \\
\hline
\end{tabular}

As it can be seen in Table 7, the operation cost of a pellet boiler system is slightly higher than the operation 
cost of a heat pump system. Therefore, it is necessary to set a payback period for costs incurred.

\section{Results and discussion}

This section presents the results of comparison of both considered heating systems. Fig. 4 shows a comparison of equipment costs, while Fig. 5 shows a comparison of operation costs.

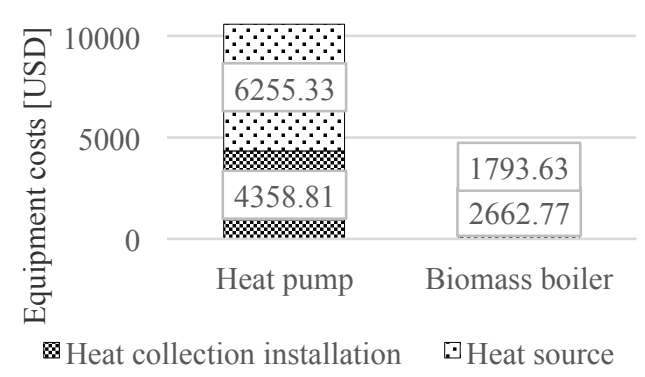

Fig. 4. Comparison of equipment cost.

The results shown in Fig. 4 indicate that the equipment costs on the heat pump is almost 3.5 times higher than on the pellet boiler. Also the costs of higher and lower heat source of heat pump is approx. 1.6 times higher than the heat collection installation of pellet boiler. The purchase costs of the installation with heat pump is calculated as the sum of costs of lower and higher heat sources. That is why these costs are significantly higher than the costs of heat collection installation working with pellet boiler. The total equipment cost of the heat pump system exceeds the total equipment cost of the biomass boiler system by approx. 2.4 times. The difference is approx. 6,158 USD. In consideration of the partial subvention [18], the cost of the heat pump over the cost of the biomass boiler will slightly decrease - to 2.3 times (the difference will be equal to approx. 4,932 USD).

Fig. 5 shows a comparison of operation costs for both heating systems. Operation costs are mainly the fuel and electricity costs, but the cost of required service inspections is also included in the case of the heat pump. The operation costs for the biomass boiler system are slightly higher than the operation costs for the heat pump system. The difference is equal to $129.14 \mathrm{USD} / \mathrm{yr}$.

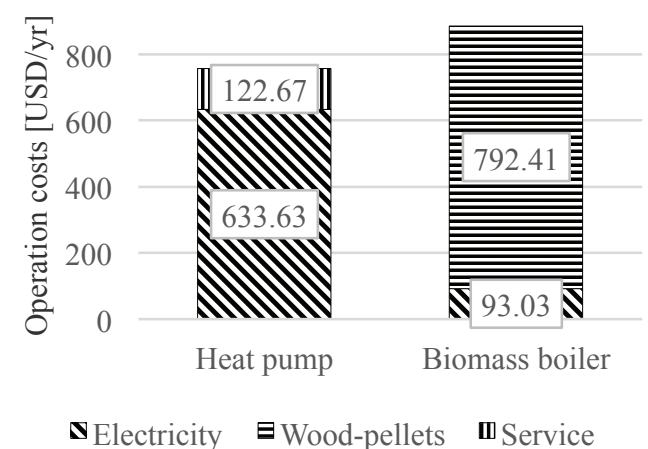

Fig. 5. Comparison of operation costs.
The simple payback period has been also calculated, i.e. after how many years the difference in operation costs between the heat pump system and the pellet boiler system equates the difference in equipment costs between those systems. This result is shown in Fig. 6 . The most optimistic scenario was took into account, in which the prices of fuels and electricity are not rising (and not decreasing); also heating systems are not failing and are working with unchanging efficiency.

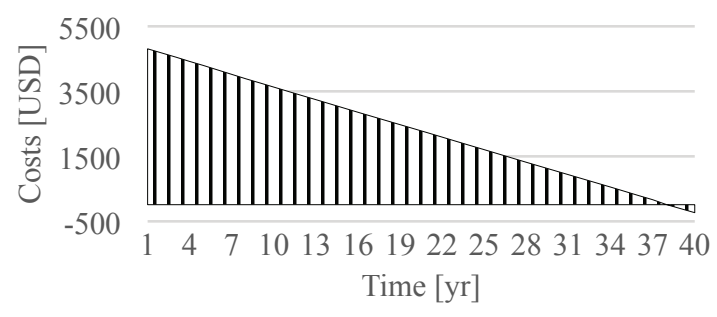

Fig. 6. The simple payback period of the heat pump system in relation to the pellet boiler system.

The results in Fig. 6 show that lower operation cost of heat pump in comparison with biomass boiler cost lets qualify heat pump as more economically justified only after 38 years of working. As stated above, the costs of potential failures are not taken into account, which in the case of heat pump may even increase the payback period. These results show that the installation with a pellet boiler is more economically justified.

For the analysed equipment, annual $\mathrm{CO}_{2}$ emissions were also determined (Fig. 7).

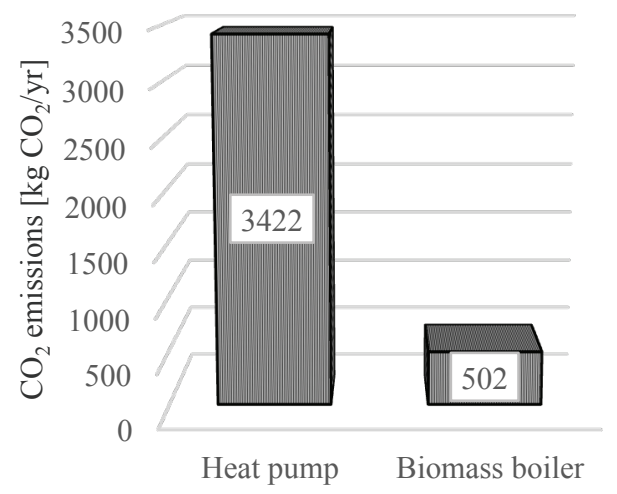

Fig. 7. Comparison of $\mathrm{CO}_{2}$ emissions.

Although the heat pump does not burn any fuel, the electricity used by the compressor or circulating pump in Poland is obtained primarily through coal combustion. Based on the $\mathrm{CO}_{2}$ emissivity factor for coal power generation (WE $=810 \mathrm{~kg} \mathrm{CO} / \mathrm{MWh}$ [21]) it was calculated that the considered heat pump produces $\mathrm{CO}_{2}$ at the level of approx. $3,341 \mathrm{~kg} \mathrm{CO} / \mathrm{yr}$. The pellet boiler also needs electricity to ensure proper operation, but it consumes much less of it what results in significantly lower $\mathrm{CO}_{2}$ emissions (approx. $503 \mathrm{~kg} \mathrm{CO}_{2} / \mathrm{yr}$ ). A level of $\mathrm{CO}_{2}$ emissions from pellet combustion equal $0 \mathrm{~kg}$ $\mathrm{CO}_{2} / \mathrm{yr}$ were assumed, because all $\mathrm{CO}_{2}$ emitted during biomass combustion is assumed to be completely absorbed by plants in the process of photosynthesis [22]. 
Those values show that biomass boiler can be described as not only more economically justified system but also as considerably more ecological in Polish conditions. It is important to emphasise that the obtained results of $\mathrm{CO}_{2}$ emissions, being results of the electricity used, are true only in Polish conditions. These results can be different depending on the specifics of the area. The results similar like for Poland can be obtained for Estonia, where more than $83 \%$ of electricity is made by fossil fuels burning [23]. But for example in Belgium [8] the heat pump shows lower $\mathrm{CO}_{2}$ emissions when compared to the biomass fuelled installation, because in Belgium electricity is obtained mainly from nuclear power plants and additionally the cost of heat from pellets combustion is compared to the cost of heat from natural gas combustion. That is why in Belgium the heat pump is more ecologically and economically justified, and the results of similar analyses should be carefully taken into account.

\section{Conclusions}

The following conclusions can be drawn based on the performed study:

1. The total equipment costs of the HP system are over two times higher than the total costs of the biomass boiler system, even if these costs are reduced by the means of the subventions.

2. The high equipment costs of the HP based system stems from the need to make installations of lower and higher heat sources, while only a heat collection installation is required for the biomass boiler.

3. The operation costs are slightly higher for the pellet boiler but the difference is only $129.14 \mathrm{USD} / \mathrm{yr}$.

4. The simple payback period shows that the higher equipment costs of the HP system in relation to the pellet boiler can be compensated by lower operation costs only after 38 years of using the HP system.

5. The analysis of $\mathrm{CO}_{2}$ emissions showed that the pellet boiler is significantly more ecological.

\section{References}

1. CSO. Housing construction - inspection tables since 1991 [Internet]. 2017 [in Polish] [cited 2017 May 08]. Available from: http://stat.gov.pl/obszarytematyczne/przemysl-budownictwo-srodkitrwale/budownictwo/budownictwo-mieszkaniowetablice-przegladowe-od-1991-roku,6,5.html

2. M. J. Stolarski, M. Krzyżaniak, K. Warmiński, D. Niksa, Energ. Conv. Manage. 121, 71 (2016)

3. M. J. Stolarski, M. Krzyżaniak, K. Warmiński, M. Śnieg, Energ. Buildings 66, 395 (2013)

4. M. Stolarski, M. Krzyżaniak, Ł. Graban, Energ. Buildings 43(2-3), 433 (2011)

5. T. Moore, Energ. Buildings 70, 463 (2014)

6. A. Saari, T. Kalamees, J. Jokisalo, R. Michelsson, K. Alanne, J. Kurnitski, Appl. Energ. 92, 76 (2012)
7. L. Gustavsson, A. Joelsson, Energ. Buildings 39(6), 717 (2007)

8. L. Georges, C. Massart, G. Van Moeseke, A. De Herde, Energ. Pol. 40, 452 (2012)

9. A. Hast, T. Ekholm, S. Syri, Sustain. Cities Soc. 22, 49 (2016)

10. L Gustavsson, Å. Karlsson, Energy 28(8), 851 (2003)

11. Ü. Alev, A. Allikmaa, T. Kalamees, Energy Proc. 78, 907 (2015)

12. Å. Karlsson, L. Gustavsson, Energy Pol. 31(14), 1541 (2003)

13. K. Mahapatra, L. Gustavsson, Energ. Effic. 3(1), 1 (2010)

14. PN-EN 12831 "Heating systems in buildings. Method for calculation of the design heat load". [in Polish]

15. Ordinance of the Minister of Infrastructure of January 14, 2002 on the definition of average standards of water consumption (Dz. U. $\mathrm{Nr} 8$, poz. 70) [in Polish]

16. G. Grabowski, Heat pumps - designer's guide, Edition I, Viessmann Academy in Poland [in Polish] (2006)

17. M. Rubik., Heat pumps in low temperature geothermal systems. MULTICO Publishing House, Warsaw, (2011), ISBN 978-83-7763-052-5 [in Polish]

18. National Fund for Environmental Protection and Water Management [Internet]. 2017 [in Polish] [cited 2017 May 12]. Available from: http://nfosigw.gov.pl/oferta-finansowania/srodkikrajowe/programy-priorytetowe/prosumentdofinansowanie-mikroinstalacji

19. A. Adamczewski, Choosing the size of the heat pump [Internet], 2017 [in Polish] [cited 2017 May 06]. Available from: http://www.instsani.pl/554 /dobor-wielkosci-pompy-ciepla

20. T. Olkowski, A. Koniecko, Ł. Przybylski, Agric. Eng. 143, 245 (2013) [in Polish]

21. KOBiZE (2017). Emissivity factors of $\mathrm{CO}_{2}, \mathrm{SO}_{2}$, $\mathrm{NO}_{\mathrm{x}}, \mathrm{CO}$ and total dust for electricity based on information from domestic data base of GHG and other substances emissions in 2015 [in Polish]

22. European Commission. Commission staff working document. Impact assessment. Accompanying document to the report from the commission to the council and the European Parliament on sustainability requirements for the use of solid and gaseous biomass sources in electricity, heating and cooling. COM(2010) 11 final SEC(2010) 66.; 2010. $54 p+$ annexes.

23. IEA Statistics, Electricity production from coal sources (\% of total) [Internet], 2015 [cited 2017 August 01]. Available from: http://data.worldbank.org/indicator/EG.ELC.COAL. ZS? view=map\&year $=2015$ 